\title{
Ultrastructural Analyses of Platelets and Fibrin Networks in BALB/c Mice after Inhalation of Spherical and Rod-Shaped Titanium Nanoparticles
}

\author{
Análisis Ultraestructural de Plaquetas y Redes de Fibrina en Ratones BALB/c \\ Después de la Inhalación de Nanopartículas de Titanio con Forma Esférica y de Barra
}

"Maria Aletta Oosthuizen; **Etheresia Pretorius; **Hester Magdalena Oberholzer \& ** Wendy Jeannette van der Spuy

OOSTHUIZEN, M. A.; PRETORIUS, E.; OBERHOLZER, H. M \& VAN DER SPUY, W. J. Ultrastructural analyses of platelets and fibrin networks in BALB/c mice after inhalation of spherical and rod-shaped titanium nanoparticles. Int. J. Morphol., 28(4):1263$1271,2010$.

SUMMARY: Engineered nanoparticles are designed to perform specific functions and therefore have specific properties that could potentially be harmful. Nanoparticles such as titanium dioxide have the potential to become transparent and are therefore widely used in cosmetic products and sunscreen. Research on the toxicity of nanoparticles is of utmost importance and numerous in vitro studies have shown that some of these particles could have adverse health effects. The current study aimed to investigate the in vivo effects of two different titanium nanoparticles at two different concentrations after inhalation by experimental BALB/c mice. This was done to determine whether these particles will cause an inflammatory reaction, visible as alterations in platelet and fibrin ultrastructure. Mice were divided into five experimental groups comprising of a control group, high and low concentration groups exposed to the sphericalshaped particles, as well as high and low concentration groups exposed to the rod-shaped particles. The ultrastructure of the fibrin networks and platelet aggregates of these experimental groups were investigated and compared to that of controls. Results indicated that the fibrin networks of the exposed animals have a net-like covering over the major fibres, typical to that found in animals with inflammation. It can therefore be concluded that the nanoparticles used in this study may have the potential to cause an inflammatory reaction, affecting the haemostatic physiology.

KEY WORDS: Nanoparticles; $\mathrm{TiO}_{2}$; Platelets; Fibrin; BALB/c murine model.

\section{INTRODUCTION}

Particulate matter (PM) is a broad term used for natural and anthropogenic particulates found in the atmosphere, which includes soil dust, soot, smoke, pollen, ash and liquid droplets. These particulates vary according to size, chemical composition and toxicity (Curtis et al., 2006). Studies on unintentionally formed ultra-fine $(<0.1 \mu \mathrm{m}$ or $100 \mathrm{~nm})$ particulates, such as those from combustion processes and welding fumes, have indicated that these particulates were more toxic than their larger counterparts (Cassee, 2006; Li et al., 2008).

The deliberate creation, through engineering processes, and application of particulates less than 100nm (in at least one diameter), is referred to as "nanotechnology" and the particulates are referred to as nanoparticles (Reinert et al., 2006). Engineered nanoparticles are designed for specific functions and therefore have specific sizes, shapes and unique properties that may enable devices and materials to be smaller and stronger and use less energy than those devices and materials currently in use.

The properties of engineered nanoparticles may be different from that of the bulk material, for example, titanium dioxide $\left(\mathrm{TiO}_{2}\right)$ nanoparticles may become transparent. This unique property is one reason why $\mathrm{TiO}_{2}$ nanoparticles are used in sunscreen and other cosmetic products (Warheit et al., 2008). The novel properties of engineered nanoparticles could potentially increase their toxicity (Reinert et al.). In

* CSIR, Natural Resources and the Environment, PO Box 395, Pretoria, 0001, South Africa.

** Department of Anatomy, School of Medicine, Faculty of Health Sciences, University of Pretoria PO Box 2034, Pretoria, 0001, South Africa. 
addition, nanoparticles have an increased surface area per unit mass, thus having a larger surface area available where reactions may take place (Warheit et al.).

Titanium, for example, is the ninth most abundant element in the earth's crust, and $\mathrm{TiO}_{2}$ is allowed in food, drugs, cosmetics and contact lenses (Toxnet, 2007). Animal studies have shown no significant fibrosis, affected structure of air spaces in the lungs or irreversible tissue reaction at concentrations as high as $10 \mathrm{mg} / \mathrm{m}^{3}$ (ACGIH, 2001). However, results of in vitro studies with $\mathrm{TiO}_{2}$ nanoparticles have shown that these particles could have adverse health effects (Hussain et al., 2005; Sayes et al., 2006).

Research on the toxicity of nanoparticles is of vital importance, because an increased understanding of the toxicological potential and mechanism of action of nanoparticles will contribute greatly to the engineering of safe nanomaterials for use in consumer products (Tetley, 2007).

As most toxicity studies on nanoparticles were in vitro (Fischer \& Chan, 2007), and in vivo conditions may produce different results, there is a need for in vivo studies to provide information for decisions on regulations. In the second UK Government Research report (HMG Report, 2007) on the risks of engineered nanoparticles, the working group on "Human Health Hazard and Risk Assessment" listed inhalation studies using nanoparticles as one of the three most important research priorities.

Hence it was decided to do an inhalation study in which animals were exposed to different concentrations of spherical and rod shaped titanium nanoparticles.
Pro-coagulant effects of ambient particulate matter, such as fine particulate matter from vehicles, have been demonstrated in human and animal studies (Holgate, 2008). It is however not known whether these same effects will be found subsequent to exposure to pure engineered nanoparticles (Holgate).

\section{MATERIAL AND METHOD}

Particles used in the study. Two types of nanoparticles (Table I) were donated by the Nanocentre, CSIR (formerly the Council for Scientific and Industrial Research), Pretoria, South Africa. The first type was commercially available and the second type had been engineered at the Nanocentre. The commercially available material was $\mathrm{TiO}_{2}$ nanoparticles (Degussa P25). This material is uncoated and consists largely of anatase (Long et al., 2007). The characteristics of the Degussa P25 particles have been described in Grassian et al., (2007). These P25 particles were used to engineer the second type of (rod-shaped) particles through a hydrothermal process at $150^{\circ} \mathrm{C}$, using potassium hydroxide $(\mathrm{KOH})$.

Two different concentrations $\left(10 \mathrm{mg} / \mathrm{m}^{3}\right.$ and $1 \mathrm{mg} /$ $\mathrm{m}^{3}$ ) of each of the two types of nanoparticles were used in this study. Before use, the different nanoparticles were suspended in phosphate buffered saline (PBS) and sonicated in a sonicator bath for 20 minutes. It was decided to use the South African occupational standard for $\mathrm{TiO}_{2}(10 \mathrm{mg} /$ $\mathrm{m}^{3}$ ) (Government Gazette, 2006), for the higher concentrations of exposure and apply an uncertainty factor of 10 to this concentration to determine the lower

Table I. Nanoparticles used in the study.

\begin{tabular}{lll}
\hline Characteristics & Spherical particles & Rod-shaped particles \\
\hline Shape & Spherical & Rod-shaped \\
Constituents & $84 \%$ anatase $: 16 \%$ rutile & $70 \%$ tetratitanate $: 30 \%$ anatase \\
BET surf ace a rea & $42.6 \pm 3.5 \mathrm{~m}^{2} / \mathrm{g}$ & $188.9 \pm 2.1 \mathrm{~m}^{2} / \mathrm{g}$ \\
\hline
\end{tabular}

Table II. Different test groups, levels of exposure, types of particles and number of animals used in the study

\begin{tabular}{lllc}
\hline Group description & Exposure level & Type of nanoparticle & Number of subjects \\
\hline Control & None & None & 6 \\
High concentrations & $10 \mathrm{mg} / \mathrm{m}^{3}$ & P25 spherical particles & 12 \\
Low concentrations & $1 \mathrm{mg} / \mathrm{m}^{3}$ & P25 spherical particles & 12 \\
High concentrations & $10 \mathrm{mg} / \mathrm{m}^{3}$ & rod-shaped particles & 12 \\
Low concentrations & $1 \mathrm{mg} / \mathrm{m}^{3}$ & rod-shaped particles & 12 \\
\hline
\end{tabular}


concentration $\left(1 \mathrm{mg} / \mathrm{m}^{3}\right)$ of exposure. The uncertainty factor was applied as these particles are in the nano-size range and thus potentially able to enter deep into the lung.

Choice of model. Previous research indicated that BALB/ c mice provide a good model to study inflammation and asthma (Oberholzer et al., 2008; Oberholzer \& Pretorius, 2009). It was therefore decided to expose BALB/c mice, to titanium nanoparticles at concentrations similar to acceptable occupational levels.

Animals used in the study. Six-week-old female BALB/ c mice, each of average weight (about 20g) were used. They were maintained in the Onderstepoort Animal Care Facility and were given OVA-free food and water ad libitum. All experimental protocols complied with the requirements of the University of Pretoria's Animal Use and Care Committee (ethics approval number H002-09). Mice were divided into test groups as in Table II.

Each test group was exposed by means of a nebuliser-venturi unit, in a whole body inhalation chamber (Glas-Col model 099C A4212) to $1.27 \mathrm{~m}^{3}$ air per hour. The frequency of exposure was one hour per day, four days per week and the total exposure duration was six weeks (days 0 to 39$)$.

Preparation of fibrin clots. On day 43, during termination, blood was drawn from each of the mice in every group and $11 \mu \mathrm{l}$ of citrate was added for every $100 \mu \mathrm{l}$ of blood drawn. The blood from each group was pooled. Blood was centrifuged at $1250 \mathrm{rpm}$ for two minutes to obtain platelet rich plasma (PRP).

Human thrombin (provided by the South African National Blood Services) was used to prepare fibrin clots (Pretorius et al., 2006). The thrombin was $20 \mathrm{U} / \mathrm{ml}$ and was prepared in a biological buffer containing $0.2 \%$ human serum albumin. When thrombin is added to PRP, fibrinogen is converted to fibrin and intracellular platelet components, such as transforming growth factor, platelet derived growth factor and fibroblastic growth factor are released into the coagulum.

Mouse PRP $(10 \mu \mathrm{l})$ was mixed with $10 \mu \mathrm{l}$ human thrombin. The PRP and thrombin mix was immediately transferred with a pipette tip to a $0.2 \mu \mathrm{m}$ Millipore membrane to form the coagulum (fibrin clot) on the membrane. This Millipore membrane was then placed in a Petri dish on filter paper dampened with PBS (to create a humid environment) and kept at $37^{\circ} \mathrm{C}$ for 10 minutes. This step was followed by a washing process with the
Millipore membranes with the coagula being placed in PBS and magnetically stirred for $120 \mathrm{~min}$. This step is necessary to remove any blood proteins trapped within the fibrin network (Pretorius et al., 2006).

Preparation of washed fibrin clot for scanning electron microscopy (SEM). Washed fibrin clots were fixed in 2.5\% gluteraldehyde in Dulbecco's phosphate buffered saline (DPBS) in a $0.075 \mathrm{M}$ phosphate buffer, at a $\mathrm{pH}$ of 7.4, for one hour. Each fibrin clot was rinsed thrice in phosphate buffer for five minutes before being fixed for one hour with $1 \%$ osmium tetraoxide $\left(\mathrm{OsO}_{4}\right)$. The samples were rinsed thrice with distilled water for five minutes and were then dehydrated serially in $30 \%, 50 \%, 70 \%, 90 \%$ ethanol and three times with $100 \%$ ethanol. The SEM procedures were completed by drying the samples with hexamethyldisilazane (HMDS) (Araujo et al., 2003), mounting, coating of the samples with ruthenium tetraoxide (RuO4) and finally examining the tissue with a JEOL 6000F FEG scanning electron microscope.

\section{RESULTS}

Figures $1 \mathrm{a}$ and $\mathrm{b}$ show a fibrin network and platelet aggregate of a control mouse. A typical fibrin network consists mainly of major, thick fibres (Label A) with minor, thin fibres dispersed among the thick fibres (Label B, Figure 1a). A platelet aggregate is seen in Figure $1 \mathrm{~b}$. Typically, aggregates show a smooth membrane surface with pores visible (black arrows). A pseudopodium on the membrane is indicated by white arrows.

Figures $2 \mathrm{a}$ and $\mathrm{b}$ show the fibrin networks and platelet aggregates in mice exposed to two concentrations of rod-shaped nanoparticles. At the lowest concentration (Figure 2a) (1 mg/m3), the thin fibres (thin white arrows) showed a netted appearance. Aggregation did seem to be impaired (thick white arrows), as the aggregates appeared much smaller than in the controls (Fig. 1b). The higher concentration $\left(10 \mathrm{mg} / \mathrm{m}^{3}\right)$ of the rod-shaped nanoparticles showed a similar netted ultrastructure, however, the netted appearance was more pronounced (Fig. 2b). Also, small platelet aggregates were trapped underneath the net (thick white arrows).

Figures $3 \mathrm{a}$ and $3 \mathrm{~b}$ show the results for the two concentrations of spherical nanoparticles. The same trends are seen as in the rod-shaped particles. Both concentrations showed a thickened net and platelets that did not aggregate the same as seen in the controls. 


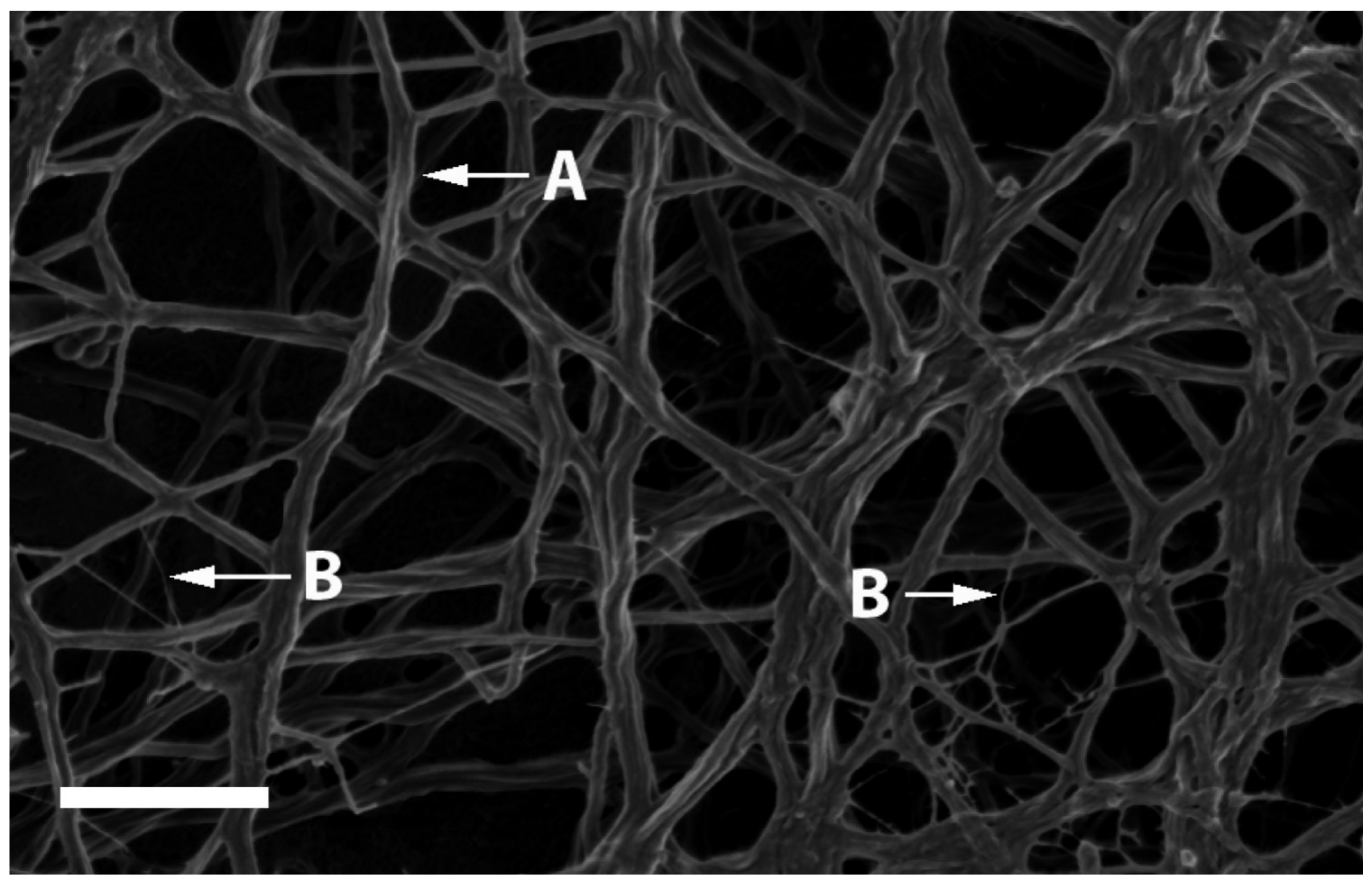

Fig. 1a: Fibrin network from control BALB/c mouse. Label A indicates thick major fibres. Label B indicates thin minor fibres. Scale $=300 \mathrm{~nm}$.

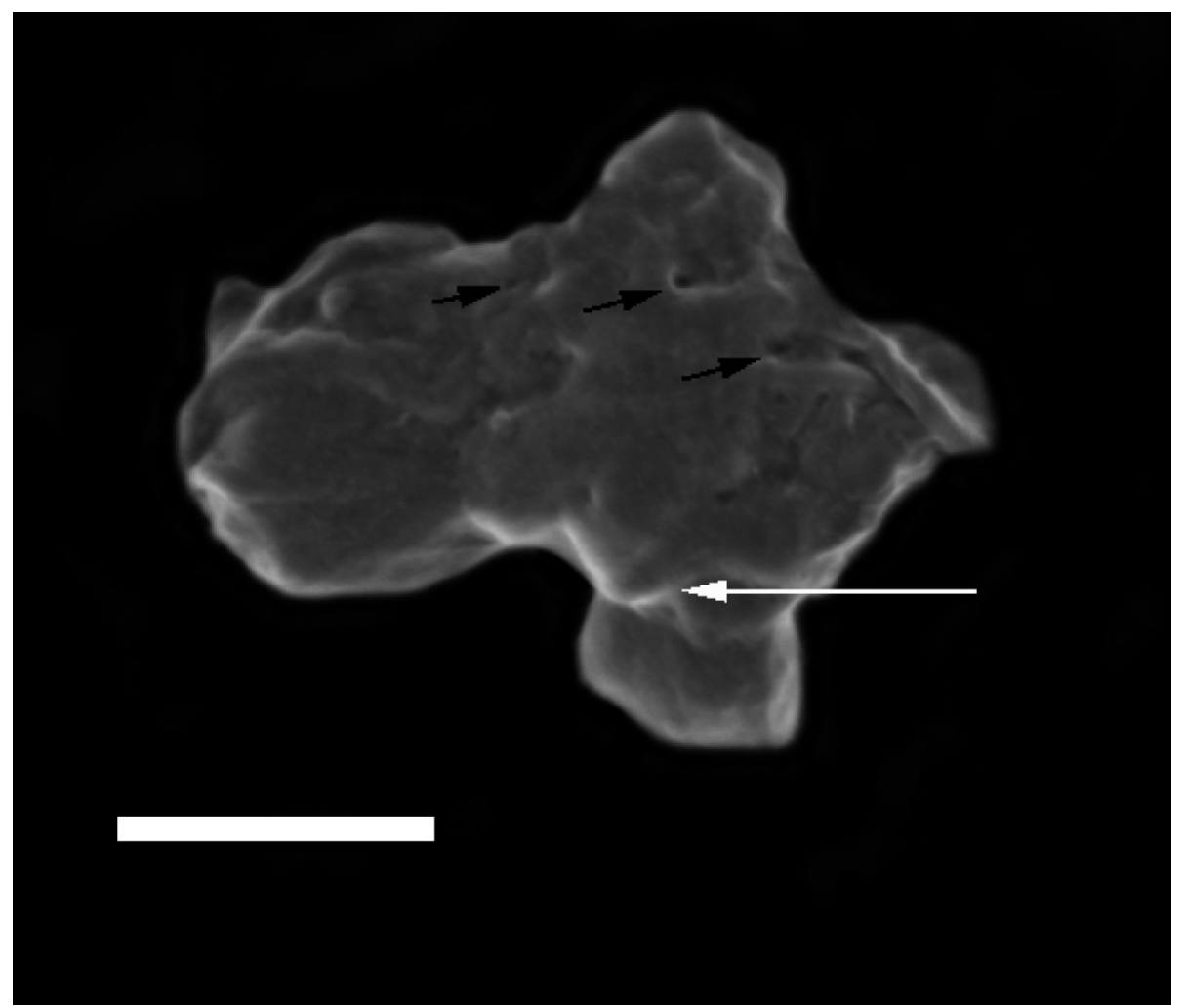

Fig. 1b: Platelet aggregate from control BALB/c mouse. Black arrows indicate membrane pores. White arrow indicates pseudopodia. Scale $=300 \mathrm{~nm}$. 


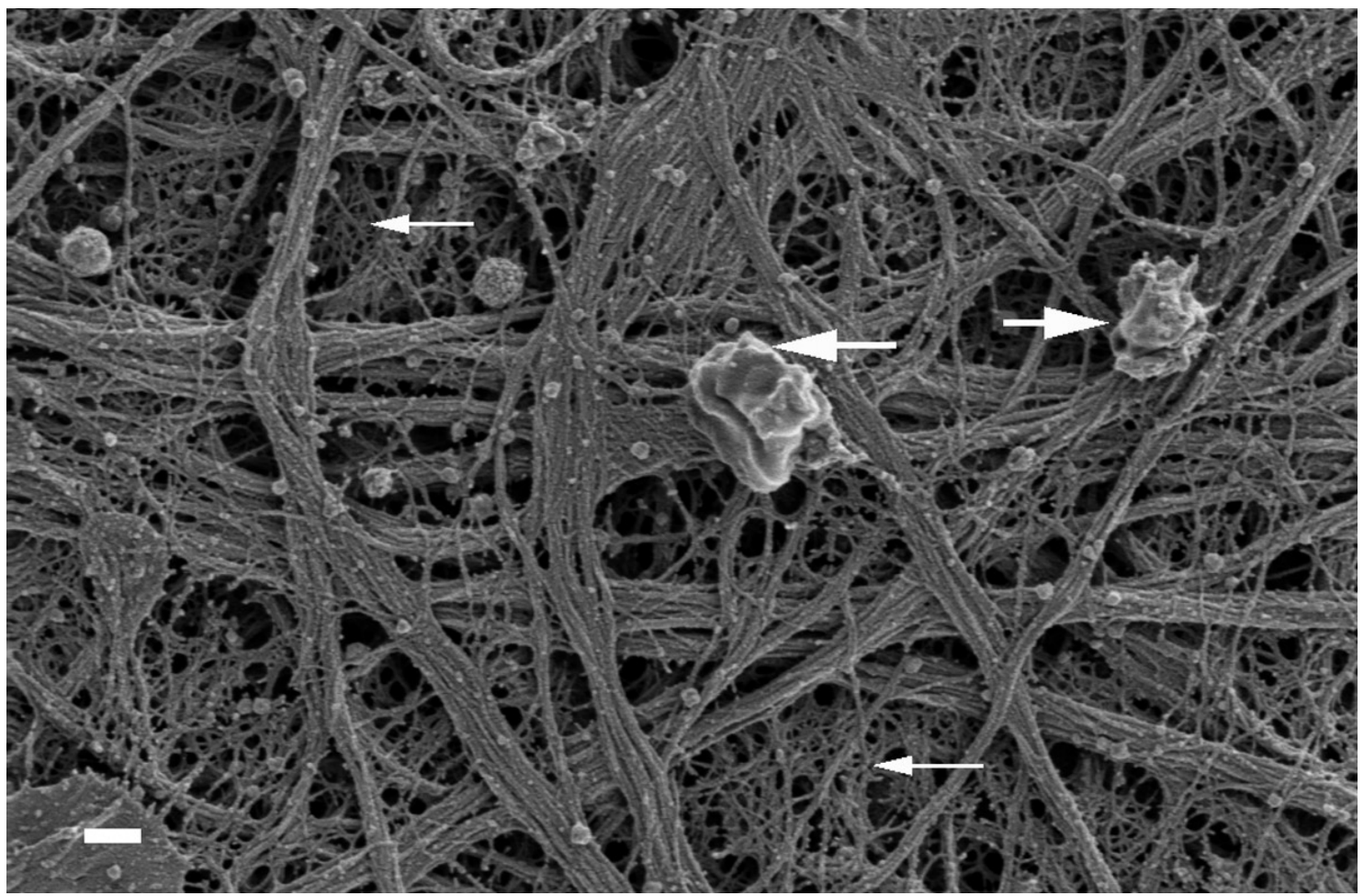

Fig. 2a: BALB/c exposure to the lower concentration $\left(1 \mathrm{mg} / \mathrm{m}^{3}\right)$ of rod-shaped nanoparticles. Thin white arrows indicate fibrin networks where minor fibres have a netlike appearance. Thick white arrows indicate small platelet aggregates. Scale $=200 \mathrm{~nm}$.

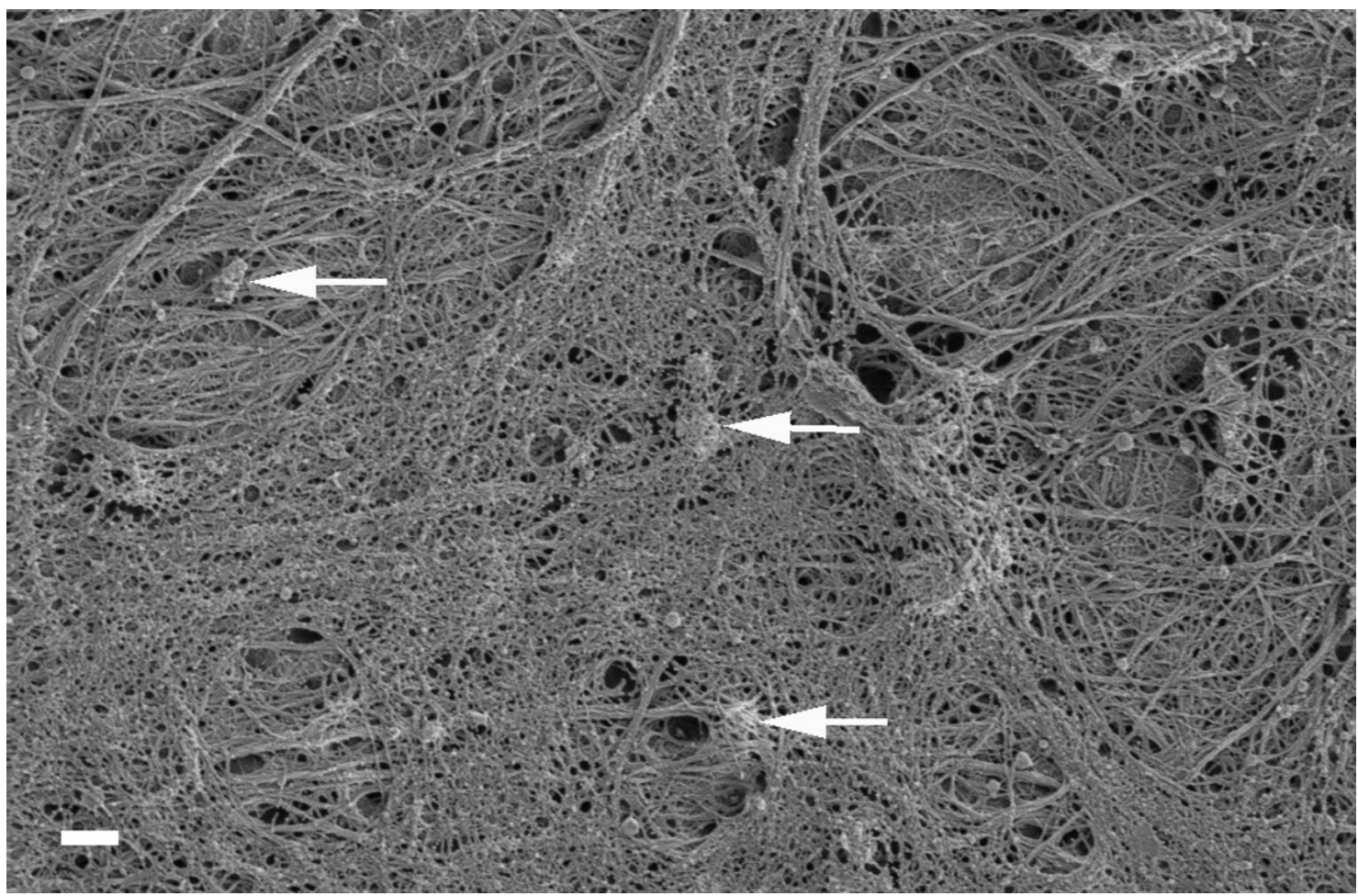

Fig. 2b: BALB/c exposure to the higher concentration $\left(10 \mathrm{mg} / \mathrm{m}^{3}\right)$ of rod-shaped nanoparticles. Fibrin networks where minor fibres have a net-like appearance covers micrograph. White arrows indicate small platelet aggregates trapped in fibrin network. Scale $=300 \mathrm{~nm}$. 


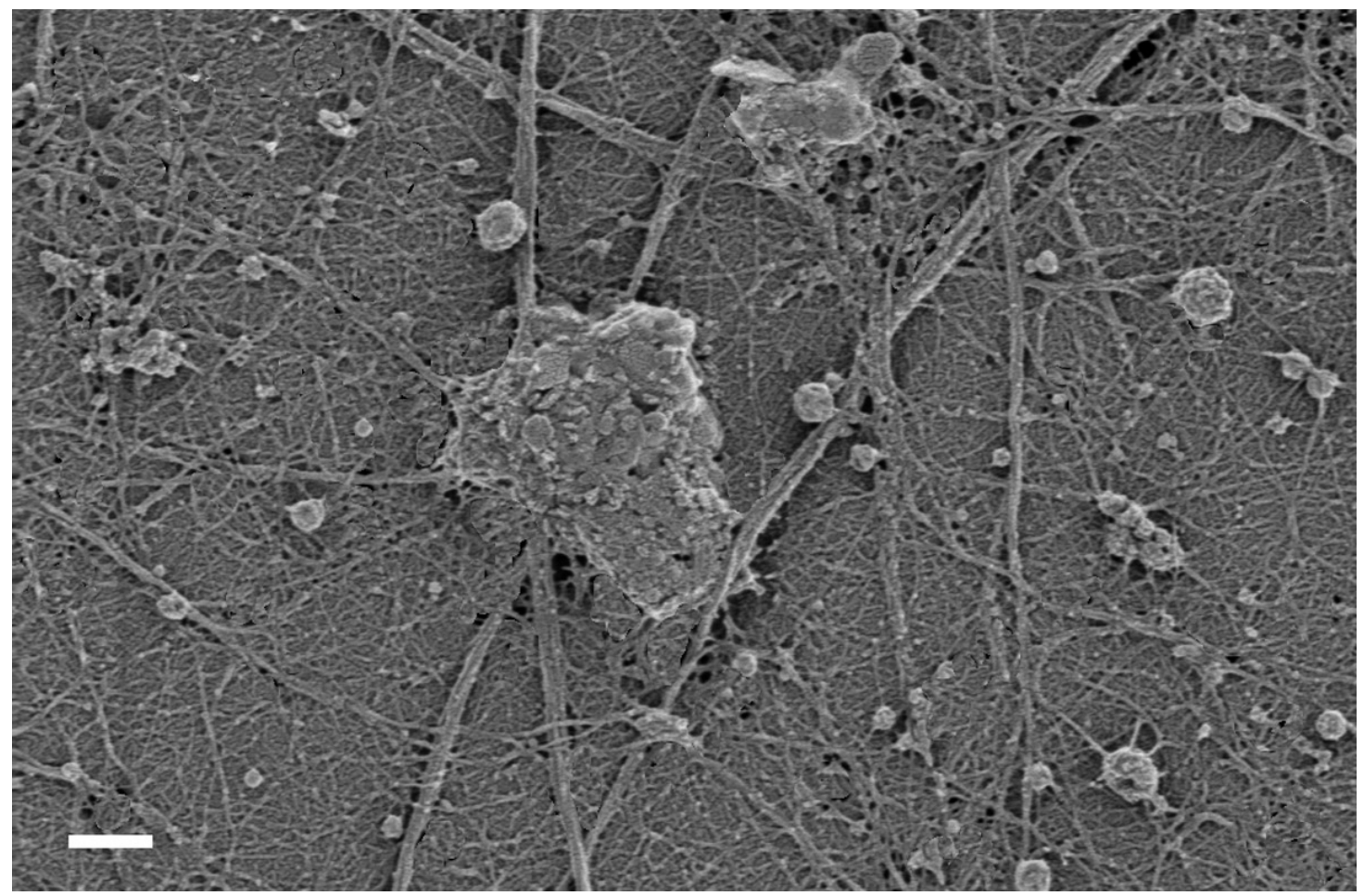

Fig. 3a: BALB/c exposure to the lower concentration $\left(1 \mathrm{mg} / \mathrm{m}^{3}\right)$ of spherical nanoparticles. Fibrin networks where minor fibres have a net-like appearance and small platelet aggregates trapped in fibrin network are shown. Scale $=200 \mathrm{~nm}$.

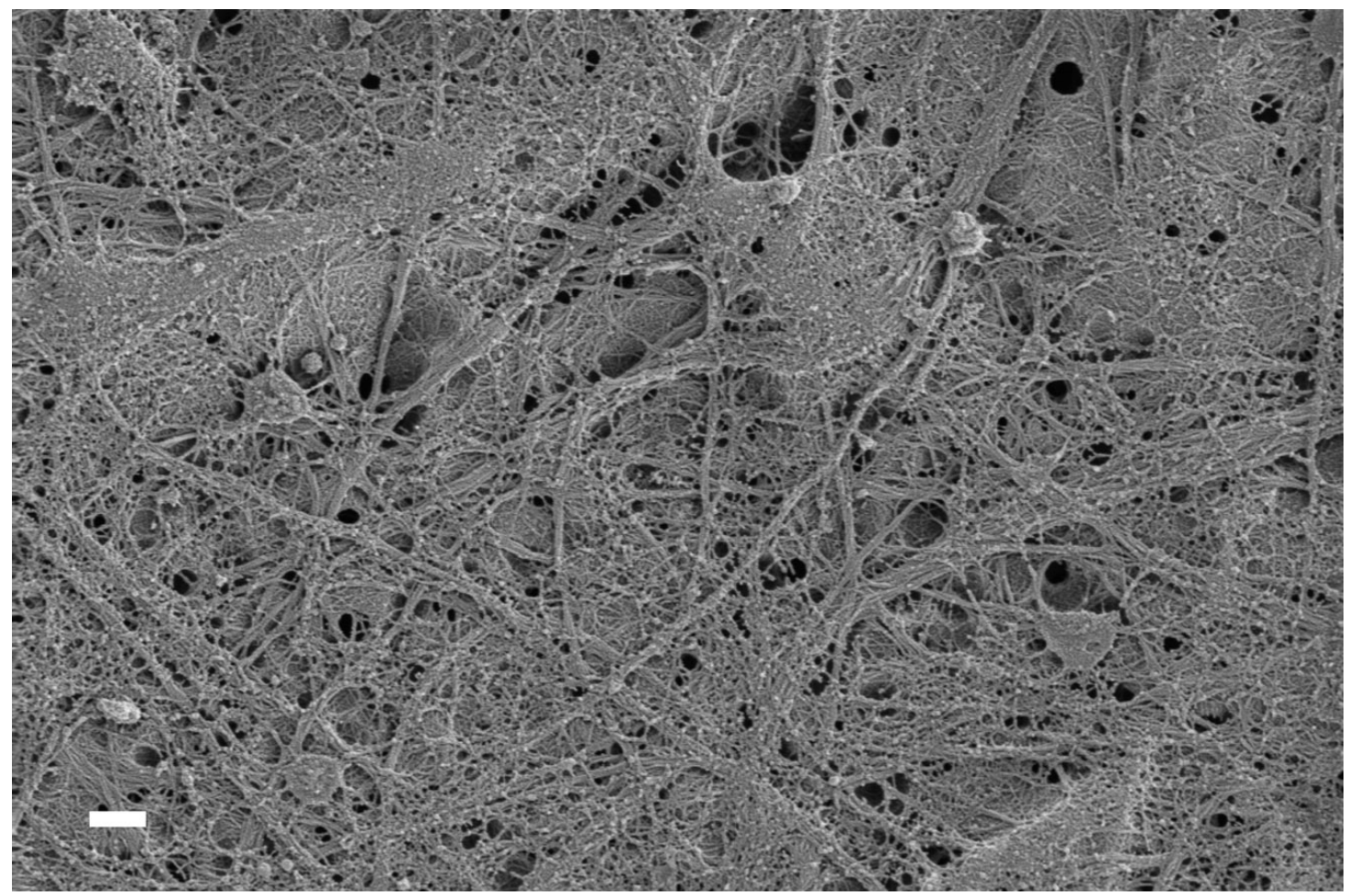

Fig. 3b: BALB/c exposure to the higher concentration $\left(10 \mathrm{mg} / \mathrm{m}^{3}\right)$ of spherical nanoparticles. Fibrin networks where minor fibres have a net-like appearance and small platelet aggregates trapped in fibrin network are shown. Scale $=300 \mathrm{~nm}$. 


\section{DISCUSSION}

The main objective of this study was to determine if two different types of titanium nanoparticles, at two different concentration ranges $\left(10 \mathrm{mg} / \mathrm{m}^{3}\right.$ and $\left.1 \mathrm{mg} / \mathrm{m}^{3}\right)$, can cause an inflammatory reaction, visible in changes in fibrin networks, in mice and ultimately humans.

Pretorius et al. (2007) were the first to use the BALB/ $\mathrm{c}$ asthma model to study ultrastructure and changes in platelet ultrastructure during asthma. Pretorius \& Oberholzer (2009), showed that similar platelet and fibrin network ultrastructure is found in uncontrolled human asthma subjects and BALB/c asthmatic animals. The challenge when using animal models is always whether the model adequately mimics the human disease; Pretorius \& Oberholzer therefore presented morphological support for the use of the animal model in the study of asthma.

Platelets play an important role in inflammation, and clinical data show that platelet activation accompanies allergen-induced bronchoconstriction in humans (Pitchford et al., 2003; Pretorius, 2008). Studies in animal models of allergic asthma have revealed the importance of platelets for acute bronchoconstriction, airway hyper-responsiveness, and bronchial wall remodelling (Pretorius et al., 2007; Pitchford et al., 2008). According to Pitchford (2007), the role of platelets in inflammation and asthma is distinct from their classically known actions performed during thrombosis and haemostasis; and include the expression of adhesion molecules and contact-dependent activation of leucocytes, the release of a plethora of inflammatory mediators, activation in cells of the adaptive immune response and the ability to migrate and undergo chemotaxis. Pitchford also mentioned that clinical data from patients suffering from asthma, allergic rhinitis and allergic dermatitis, reveal changes in platelet behaviour and function during or after allergen exposure. It is therefore useful to use platelets and fibrin to study inflammation and diseases that are associated with inflammation, such as asthma.

Platelet activation (acceleration of coagulation) had been demonstrated in vitro using platelet-rich blood plasma from healthy human donors and silver nanoparticles (Stevens et al., 2009). Carbon nanotubes induced platelet aggregation in vitro. Agglomorates of platelets were also seen. The same effect was however not found with purified fullerines (Radomski et al., 2005). In addition, enhanced thrombosis was found in vivo in rats following infusion of carbon nanotubes (Radomski et al., 2005).

The current research therefore compares control (not exposed to nanoparticles) BALB/c platelets and fibrin networks, to previously studied platelet and fibrin morphology of animals exposed to two types of titanium nanoparticles, each at two concentration ranges.

It is suggested that exposing $B A L B / c$ animals to the nanoparticles used in this study caused fibrin networks to have a net-like appearance also seen during inflammation. The nanoparticles used in this study may therefore have the potential to cause a reaction in $\mathrm{BALB} / \mathrm{c}$ animals that show similar attributes to inflammation. This may also suggest that humans exposed to these particles, for example in an occupational environment, should be particularly aware that the particles may induce allergic reactions to people prone to asthma. This statement, however, needs further investigation.

ACKNOWLEDGEMENTS. The authors wish to express their gratitude to the rest of the team members involved in this project as well as the SANBS for providing the thrombin used in this study. We wish to acknowledge the CSIR and Department of Anatomy, University of Pretoria who funded the laboratory and animal study.

OOSTHUIZEN, M. A.; PRETORIUS, E.; OBERHOLZER, H. M \& VAN DER SPUY, W. J. Análisis ultraestructural de plaquetas y redes de fibrina en ratones BALB/c después de la inhalación de nanopartículas de titanio con forma esférica y de barra. Int. J. Morphol., 28(4):1263-1271, 2010.

RESUMEN: Las nanopartículas han sido diseñadas para realizar funciones específicas, y por lo tanto, tienen propiedades específicas que podrían ser perjudiciales. Las nanopartículas, como el dióxido de titanio tienen el potencial de llegar a ser transparentes, pudiendo ser ampliamente utilizadas en productos cosméticos y protectores solares. La investigación sobre la toxicidad de las nanopartículas es de suma importancia y numerosos estudios in vitro han demostrado que algunas de estas partículas, podrían tener efectos adversos para la salud. El presente estudio tuvo como objetivo investigar los efectos in vivo de dos nanopartículas de titanio diferentes en dos concentraciones después de la inhalación experimental de ratones BALB/ c. Esto se realizó para determinar si las partículas provocan una reacción inflamatoria, visible como alteraciones en la ultraestructura de plaquetas y fibrina. Los ratones se dividieron en cinco grupos experimentales, que comprende un grupo control y grupos expuestos a nanopartículas de forma esférica de alta y baja concentración, así como grupos expuestos a nanopartículas en forma de barra de alta y baja concentración. Fueron investigadas la ultraestructura de las redes de fibrina y agregados plaquetarios de estos grupos experimentales y se comparó con la de los controles. Los resultados indicaron que en los animales expuestos se observó una red de fibrina que recubría las fibras más grandes, típicas de las que se encuentran en los animales con inflamación. Por lo tanto, puede concluirse que las nanopartículas utilizadas en este estudio pueden tener el potencial de causar una reacción inflamatoria, afectando a la fisiología hemostática.

PALABRAS CLAVE: Nanopartículas; $\mathrm{TiO}_{2}$; Plaquetas; Fibrina; Modelo murino BALB/c. 


\section{REFERENCES}

ACGIH. American Conference of Governmental Industrial Hygienists. Documentation of the Threshold Limit Values and Biological Exposure Indices. $7^{\text {th }}$ ed. ISBN 978-1-882417-43-8, 2001.

Araujo, J. C.; Téran, F. C.; Oliveira, R. A.; Nour, E. A.; Montenegro, M. A.; Campos, J. R.; et al. Comparison of hexamethyldisilazane and critical point drying treatments for SEM analysis of anaerobic biofilms and granular sludge. J. Electron. Microsc., 52:429-33, 2003.

Cassee, F.R. Toxicity of automotive and ultrafine particles. Toxicol, Lett., 164:S14, 2006.

Curtis, L.; Rea, W.; Smith-Willis, P.; Fenyves, E. \& Pan, Y. Adverse health effects of outdoor air pollutants. Environ. Int., 32:815-30, 2006.

Fischer, H. C. \& Chan, W. C. W. Nanotoxicity: the growing need for in vivo study. Curr. Opin. Biotechnol., 18:1-7, 2007.

Government Gazette. Gazette number 29276 of 5 October, 2006

Grassian, V. H.; Adamcarcova-Dodd, A.; Pettibone, J. M.; O'Shaughnessy, T. O. \& Thorne, P.S. Inflammatory Response of Mice to Manufactured Titanium Dioxide Nanoparticles: Comparison of Size Effects through Different Exposure Routes. Nanotoxicology, 1:211-26, 2007.

HMG Report. Characterising the potential risks posed by engineered nanoparticles; A second UK Government research report, 2007. Available in: http:// www.defra.gov.uk/environment/quality/nanotech/ documents/nanoparticles-riskreport07.pdf

Holgate, S. Exposure, Uptake, Distribution and Toxicity of Nanomaterials, 2008. Available in: http:// www.rcep.org.uk/reports/27nove1\%20materials/ documents/exposure_uptake_toxicology.pdf

Hussain, S. M.; Hess, K. L.; Gearhart, J. M.; Geiss, K. T. \& Schlager, J. J. In vitro toxicity of nanoparticles in BRL 3A rat liver cells. Toxicol. In Vitro, 19:975-83, 2005.

Li, N. ; Xia, T. \& Nel, A. E. The role of oxidative stress in ambient particulate matter-induced lung diseases and its implications in the toxicity of engineered nanoparticles. Free Radic. Biol. Med., 44:1689-99, 2008.
Long, T. C.; Tajuba, J.; Sama, P.; Saleh, N.; Swartz, C.; Parker, J.; et al. Nanosize Titanium Dioxide Stimulates Reactive Oxygen Species in Brain Microglia and Damages Neurons in vitro. Environ. Health Perspect., 115:1631-7, 2007.

Oberholzer, H. M.; Pretorius, E.; Smit, E.; Ekpo, O. E.; Humphries, P.; Auer, R. E. \& Bester, M. J. Investigating the effect of Withania somnifera, Selenium and Hydrocortisone on blood count and bronchial lavage of experimental asthmatic Balb/c mice. Scand. J. Lab. Aim. Sci., 35:239-48, 2008.

Oberholzer, H. M. \& Pretorius, E. Investigating lung remodelling in Modul8®-treated Balb/c asthmatic animals. Micron, 40:775-82, 2009.

Pitchford, S. C.; Yano, H.; Lever, R.; Riffo-Vasquez, Y.; Ciferri, S.; Rose, M. J.; et al. Platelets are essential for leukocyte recruitment in allergic inflammation. $J$. Allergy Clin. Immunol., 112:109-18, 2003.

Pitchford, S. C. Defining a role for platelets in allergic inflammation. Biochem. Soc. Trans., 35:1104-8, 2007.

Pitchford, S. C.; Momi, S.; Baglioni, S.; Casali, L.; Giannini, S.; Rossi, R.; et al.Allergen induces the migration of platelets to lung tissue in allergic asthma. Am. J. Respir. Crit. Care Med., 177:604-12, 2008.

Pretorius, E.; Briedenhann, S.; Marx, J. \& Franz, R. C. Structural changes in the fibrin network of a pretoria family with dysfibrinogenemia: a scanning electron microscopical study. Ultrastruct. Pathol., 30:167-76, 2006.

Pretorius, E.; Ekpo, O. E. \& Smit, E. Comparative ultrastructural analyses of platelets and fibrin networks using the murine model of asthma. Exp. Toxicol. Pathol., 59:105-14, 2007.

Pretorius, E. \& Oberholzer, H. M. Ultrastructural changes of platelets and fibrin networks in human asthma: a qualitative case study. Blood Coagul. Fibrinolysis, 20:146-9, 2009.

Pretorius, E. The role of platelet and fibrin ultrastructure in identifying disease patterns. Pathophysiol. Haemost. Thromb., 36:251-8, 2008. 
OOSTHUIZEN, M. A.; PRETORIUS, E.; OBERHOLZER, H. M \& VAN DER SPUY, W. J. Ultrastructural analyses of platelets and fibrin networks in BALB/c mice after inhalation of spherical and rod-shaped titanium nanoparticles. Int. J. Morphol., 28(4):1263-1271, 2010.

Radomski, A.; Jurasz, P.; Alonso-Escolano, D.; Drews, M.; Morandi, M.; Malinski, T.; et al. Nanoparticle-induced platelet aggregation and vascular thrombosis. $\mathrm{Br} . \mathrm{J}$. Pharmacol., 146:882-93, 2005.

Reinert, K.; Andrews, L. \& Keenan, R. Nanotechnology Nexus - Intersection of Research, Science, Technology and Regulation. Hum. Ecol. Risk Assess.,12:811-8, 2006.

Sayes, C. M.; Wahi, R.; Kurian, P. A.; Liu, Y.; West, J. L.; Ausman, K. D.; et al. Correlating nanoscale titania structure with toxicity: a cytotoxicity and inflammatory response study with human dermal fibroblasts and human lung epithelial cells. Toxicol. Sci., 92:174-85, 2006.

Stevens, K. N.; Crespo-Biel, O.; van den Bosch, E. E.; Dias, A. A.; Knetsch, M. L.; Aldenhoff, Y. B.; et al. The relationship between the antimicrobial effect of catheter coatings containing silver nanoparticles and the coagulation of contacting blood. Biomaterials, 30:368290, 2009.

Tetley, T. D. Health effects of nanomaterials. Biochem. Soc. Trans., 35:527-31, 2007.

Toxnet. Titanium dioxide, 2007. Available in : http:// toxnet.nlm.nih.gov/cgi-bin/sis/search/f?./temp/ $\sim$ RdQTIs:3:BASIC

Warheit, D. B.; Sayes, C. M.; Reed, K. L. \& Swain, K. A. Health effects related to nanoparticle exposures: environmental, health and safety considerations for assessing hazards and risks. Pharmacol. Ther., 120:3542, 2008 .
Correspondence to:

Etheresia Pretorius

BMW Building

PO Box 2034

Faculty of Health Sciences

University of Pretoria

Pretoria, 0001

SOUTH AFRICA

Tel: +27 123192533

Fax: +27 123192240

Email: resia.pretorius@up.ac.za

Received: 06-10-2010

Accepted: 12-11-2010 
